\title{
Arbitration Agreement: The Issue of Arbitrability in Nigeria Arbitration Practice
}

\author{
Greg Chukwudi Nwakoby, Charles Emenaogha Aduaka, Chiamaka Ifeatu Orabueze
}

Department of international Law and Jurisprudence, Faculty of Law, Nnamdi Azikiwe University, Awka, Nigeria

Email address:

gregnwakoby2@yahoo.com (G. C. Nwakoby)

\section{To cite this article:}

Greg Chukwudi Nwakoby, Charles Emenaogha Aduaka, Chiamaka Ifeatu Orabueze. Arbitration Agreement: The Issue of Arbitrability in Nigeria Arbitration Practice. International Journal of Law and Society. Vol. 1, No. 2, 2018, pp. 92-101. doi: 10.11648/j.ijls.20180102.16

Received: January 5, 2018; Accepted: February 25, 2018; Published: March 21, 2018

\begin{abstract}
Arbitration agreement is the bedrock of every arbitral proceedings and it is the corner stone of the jurisdiction vested on the arbitrators to arbitrate on any matter referred to them. The agreement could take various forms and character (oral or written) depending on the governing law. It is not all issues and subject matters that are arbitrable. Different national legislation and public policy have limited the scope of arbitration with respect to the issue of arbitrability. Not all matters are capable of being referred to arbitration. Certain matters are reserved for the court alone and if an arbitral tribunal purports to deal with them the resulting award will be unenforceable. We have arbitrability based on agreement and arbitrability based on law and public policy. In this work, efforts shall be made to address all issues with respect to arbitration agreement under the Act and the concept of arbitrability.
\end{abstract}

Keywords: Arbitration Agreement, Arbitrability in Nigeria, Arbitration Practice

\section{Introduction}

Arbitration is one form of Alternative Dispute Resolution Mechanism (ADR). It is an alternative to litigation and it is a private exercise based on the agreement of the parties. Some scholars have argued and attempted to exclude arbitration from ADR as according to such scholars, arbitration is technical just like litigation. Though one does not intend to go into the argument on whether arbitration is a form of ADR or not. Suffice it to state that arbitration is neither court nor litigation. An arbitrator is neither a judge nor a magistrate. $\mathrm{He}$ is not a judicial officer in the constitutional sense. The technicality and hardship in arbitration are all dependent on the agreement of the parties and the governing law. Where the parties in their agreement specified a very simple procedure for the arbitration, invariably the arbitration will be simple. Where the state wherein the arbitration is taking place has amended and modified their arbitral rules in accordance with the UNCITRAL Model law, then the arbitration proceedings will be very fast, efficient, simple and less technical. The problem is that some national arbitration rules are tailored towards their High Court Rules. For such States, arbitration in their jurisdiction will certainly be technical and less efficient. However, whether technical or not, arbitration is not litigation and cannot also be court.

Arbitration is a private process based on the agreement of the parties. In fact, the saying "no agreement no arbitration" is basic in every arbitration process. It is the agreement of the parties that confers jurisdiction on the arbitral tribunal. Only parties who have contractual capacity can enter into arbitration agreement. This is because the same principle of capacity in simple contract applies to arbitration. An infant cannot enter into arbitration agreement unless it is for his welfare or for the supply of necessaries.

Arbitration agreement has variously been defined by scholars, jurist and text writers. For the purpose of this work; we shall refer to only but few of such definitions. According to Russell, arbitration agreement means an agreement to submit to arbitration present or future disputes (whether they are contractual or not). ${ }^{1}$ This is a total departure from the definition in the 18th edition of Russell wherein arbitration was defined to mean a written agreement to submit present or future differences to arbitration whether an arbitrator is

\footnotetext{
1 David St John Sutton, Russell on Arbitration, $22^{\text {nd }}$ Ed. Sweet \& Maxwell Ltd 2003, 26. Russell distinguished between arbitration agreement and submission agreement. Arbitration agreement refers to agreement to refer present and future disputes to arbitration whereas submission refers to an agreement to refer a present dispute which has occurred to arbitration.
} 
named therein or not. ${ }^{2}$ According to John Paris, arbitration is the submission of a dispute between two or more parties for the decision by a third party of their choice. ${ }^{3}$ However, for Ronald Bernstein, arbitration is an agreement of the parties that a dispute between them be settled by a tribunal of their choice. $^{4}$ The Supreme Court of Nigeria in M. V. Lupex v. N. O. C. \& S. Ltd ${ }^{5}$ defined arbitration clause as "a written submission agreed by the parties to the contract and, like other written submissions, it must be construed according to the language and in the light of the circumstances in which it is made."'The court in Nwanenang $v$. Ndarake \& ors $^{6}$ defined arbitration as "a reference to the decision of one or more persons with or without an umpire of a particular matter in difference between the parties." Halsbury's Laws of England defined arbitration as "the reference of a dispute or difference or differences between not less than two parties for determination, after hearing both sides in a judicial manner, by a person or persons other than a court of competent jurisdiction". 7 This definition by Halsbury's Laws of England represents the correct and well articulate elements of the subject matter. Arbitration must be based on an agreement of the parties for it to be valid. The arbitration must be with reference to dispute or differences which have occurred or are to occur in the future, arbitration is not court in the legal sense and the arbitrators are under a duty to hear the parties and their witnesses fully before making an award. This definition lay to rest the argument whether arbitration is ADR or litigation. The definition in its concluding part stated that it is a determination of dispute ( $\mathrm{s}$ ) by person or persons other than by a court of competent jurisdiction. The implication therefore is that arbitration is an alternative to court hence a form of ADR. The definition by Halsbury's laws of England was affirmed by the Supreme Court of Nigeria as plausible and an acceptable working definition in NNPC v. Lutin Invest. Ltd. $^{8}$

\section{Arbitration Agreement under the Act}

We have different forms of arbitration agreements. We have arbitration agreements under the common law, customary law, and the Act. The arbitration agreement under the customary law and common law are required to be oral whereas the arbitration agreement under the Act shall be in writing for it to be valid and enforceable. It can be one of three types namely; a Scott v. Avery clause which provides that unless and until arbitration has been resorted to, the

2 Ibid $18^{\text {th }}$ Ed. 38. Russell in its $18^{\text {th }}$ edition confused two different forms of arbitration agreement. Arbitration based on oral arbitration agreement which relates to common law and customary law arbitration respectively. Arbitration agreement in writing relates to arbitration under the Act.

3 John Paris, The Law and Practice of Arbitration, George Godwin Ltd, Great Britain, 1974, 1

4 Ronald Berstein, Handbook of Arbitration Practice, 8.

5 (2003) 15 NWLR (Pt. 844) 469 at 487.

6 (2013) LPELR 20720. Agala v. Okusim (2010) 10NWLR (pt. 1220) 412 at 488.

Ihunwo v. Ihunwo (2014) AllFWLR 1444 at 1453

7 Halsbury's Laws of England, $3^{\text {rd }} \mathrm{Ed}, 38$.

8 (2006) NSCQR 77 at 112 parties may not litigate the matter (named after the very old case of Scott v. Avery in which the clause and its effects were first examined by the courts). ${ }^{9}$ The clause is indeed the preference of the spirit of Article 8 of the UNCITRAL Model Law and sections $4 \& 5$ of the Arbitration and Conciliation Act of Nigeria, an Atlantic Shipping Clause which required the parties to go to arbitration within a specified time frame or the right to arbitrate would abate by the effluxion of time, or a Union of India Clause named after the case in which the clause and its effects were first examined by the courts wherein the clause grants only one of the parties right of recourse to arbitration. ${ }^{10}$ In Nigeria, the form and nature of arbitration agreement under the Act are set out in the Arbitration and Conciliation Act Cap A18 Laws of the Federation of Nigeria, 2004. Section (1) of the Act provides thus;

1. Every arbitration agreement shall be in writing contained -

a. In a document signed by the parties.

b. In an exchange of letters, telex, telegrams or other means of communication which provide a record of the arbitration agreement; or

c. In an exchange of points of claim and of defence in which the existence of an arbitration agreement is alleged by one party and not denied by another.

2. Any reference in a contract to a document containing an arbitration clause constitutes an arbitration agreement if such contract is in writing and the reference is such as to make that clause part of the contract. $^{11}$

Section 1 of the Act requires that both parties will have to sign the agreement in accordance with the provisions of section 1 (a) of the Act for it to be valid and enforceable. It is important to state that it is not always that the parties must jointly sign the document of the arbitration agreement for it to be valid and enforceable. The requirement of the signature of the parties on a single document will be dependent on the nature of the subject matter and the document of agreement involved. ${ }^{12}$ Where the arbitration agreement is in the form of the documents set out in section (1) (b) \& (c), it will be sufficient if the respective documents evidencing arbitration agreement are signed by their individual makers. This is because the parties shall neither be expected to jointly sign a letter together nor be expected to jointly sign a common telex of fax document. The plaintiff and the defendant cannot jointly sign the statement of claim together. The nature of signature required will be dependent on the form and nature of the document of the arbitration agreement.

Unless otherwise agreed by the parties, an arbitration agreement is not discharged by the death of a party and may be enforced by or against the personal representatives of the

\footnotetext{
9 (1856) 5 HL Cas. 811

10 Union of India v. Bhoriat Engineering Corp. LLR Delhi Series (1971) Vol. 2, 57

11 Arbitration and Conciliation Act Cap A18 Laws of the Federation of Nigeria 2004, section 1 (a) (b) (c)\&(2).

12 Re Thompson (1894) QB 462. Tinplate Co. v. Hughes (1891) 60 LJ 189.
} 
parties. ${ }^{13}$ The Arbitration and Conciliation Act of Nigeria provides that an agreement shall not be invalid by reason of the death of any party thereto but shall, in such an event, be enforceable by or against the personal representative of the deceased. ${ }^{14}$ This provision of the Act is subject to the common law maxim actio personalis moritur cum persona which provides that personal action dies with the person. By implication, section 3 of the Act does not affect the operation of an enactment or rule of law by virtue of which a substantive right or obligation is extinguished by death.

Arbitration agreement once entered into by the parties' remains binding on them unless discharged by the parties based on agreement or set aside with the leave of court or judge. The implication of this principle is that an arbitration agreement is irrevocable unless discharged by the parties themselves or impeached by the court at the instance of either party to the agreement. Section 2 of the Arbitration and Conciliation Act provides that unless a contrary intention is expressed therein, an arbitration agreement shall be irrevocable except by agreement of the parties or by leave of the court or a judge. ${ }^{15}$

It is very unfortunate that section 2 of the Act did not furnish us with the grounds pursuant to which a court or a judge may impeach, set aside or discharge an arbitration agreement. Arbitration agreement is a simple contract and any of the grounds for the successful impeachment of simple contract will suffix. The grounds for impeachment of arbitration agreement would among others include the following:

a) Formal invalidity of the arbitration agreement.

b) Arbitrability of the subject matter.

c) Capacity of the contracting parties.

d) Fraud, undue influence and improper procurement.

e) Misrepresentation.

An arbitration agreement shall pursuant to the provisions of section 2 of the Act be impeached by the court if the applicant for leave furnishes the court with evidence of any of these grounds listed above. Where parties have entered into arbitration agreement, none of them has right to revert to the court for redress with respect to the subject matter of the arbitration agreement without first referring the matter or dispute to the arbitrator for determination. Where a party contrary to the arbitration agreement refers their dispute of differences to court, the aggrieved party is not without remedy. The aggrieved party has the right to treat it as a breach of contract and then sue for award of damages under the common law. He may also sue for specific performance of the arbitration agreement. ${ }^{16}$

The aggrieved party whose matter was referred to the court by the other party has a right to apply for stay of proceedings. The application for stay of proceedings has to be made to the very court which has the original jurisdiction in the matter

13 David St. John Sutton, Russell on Arbitration $22^{\text {nd }}$ Ed. 435

14 Section 3 of the Act.

15 Section 2 of the Act.

16 Royal Exchange Assurance v. Bentworth Finance Nig. Ltd. (1976) 6 UILR (Pt.

2) 293. and who would have heard the case but for the arbitration agreement. ${ }^{17}$ The application has to be made before the applicant takes a step in the proceedings. Where the applicant takes a step in the proceedings before applying for stay of proceedings, the court will definitely not grant the application as he has waived his right. ${ }^{18}$ The implication of this principle of law is that the applicant has to apply for stay of proceedings before taking any positive or pragmatic step in furtherance of the proceedings in the court. Sections $4 \& 5$ of the Arbitration and Conciliation Act provides inter alia

4. A court before which an action, which is the subject of an arbitration agreement is brought shall, if any party so requests not later than when submitting his first statement on the substance of the dispute, order a stay of proceedings and refer the parties to arbitration. ${ }^{19}$

5. If any party to arbitration agreement commences any action in any court with respect to any matter which is the subject of an arbitration agreement, any party to the arbitration agreement may, at any time after appearance and before delivering any pleading or taking any other step in the proceedings, apply to the court to stay proceedings. ${ }^{20}$

It is the duty of the court to compel the parties to comply with the terms of their agreement without jumping the queue. ${ }^{21}$ In Hallam v Attorney General Plateau State ${ }^{22}$ the court held that:

Where an agreement made by the parties stipulates that any dispute arising there from must first be referred to a referee, it would amount to jumping the queue for any of the parties to resolve to go to the court first before the dispute between the parties is referred to an appointed referee.

From the foregoing, the application has to be made by the applicant before taking any legal procedural step to acknowledge the legal proceedings against him in court. On the strength of the application made pursuant to sections 4 \& 5 , the court shall grant a stay of proceedings unless in the contrary the court is satisfied that the arbitration agreement is null and void, inoperative, incapable of being performed or that the applicant is not serious and committed in commencing arbitration proceedings as he has failed, refused, and neglected to appoint his own arbitrator or take other necessary steps to promote arbitral proceedings after the other party has done everything to ensure that arbitration takes place.

Arbitration agreement serves a lot of purposes and is the legal basis and the corner stone of every arbitration practice. It is the arbitration agreement that confers jurisdiction on the arbitral tribunal to arbitrate in the matter; it specifies the

\footnotetext{
17 Afcon Nig. Ltd. V. Registered Trustees of Ikoyi Club (1996) FHCLR 371. 18 Obemba v. Wemabod Estate (1977) 5SC 115.

19 Arbitration and Conciliation Act section 4 (1).

20 Arbitration and Conciliation Act section 5 (1).

21 KSUDB V. Fanz Construction Co. Itd (1990) 4 NWLR (Pt. 142) 1). Hallam v. Attorney General Plateau State (supra). 249. Commerce Assurance v. Alli (1992) 3NWLR (Pt. 232) 701.. Bebeji Oil Allied Products Ltd \& Anor v. Pancosta Ltd. (2007) 31 WRN 163. BSG Energy Holding Ltd v. Spears (2013) 31 WRN 146. 22 ibid.
} 
venue of arbitration, the language, time for arbitration, applicable law, and procedure for arbitration, the name and the number of arbitrators. The arbitration agreement plays a major role in arbitration.

It must be emphasized at this point that not all matters can be referred to arbitration. There are matters which cannot be referred to arbitration on the basis of public policy and legislation. There are matters also which cannot be referred to arbitration on the basis of the agreement of the parties.

\section{Arbitrability}

Arbitrability touches on the capacity and jurisdiction of the arbitrator (s) or the arbitral tribunal to undertake arbitration with respect to any matter referred to them. It is a jurisdictional matter. It refers to whether or not arbitrators have the authority to determine a dispute. This in turn depends on whether certain parties have agreed to have certain dispute between them resolved or determined through arbitration. Arbitrable issues are the conditions that must be fulfilled and met for arbitration proceedings to go forward. It relates to such issues as whether there was an agreement between the parties to arbitrate, ${ }^{23}$ whether arbitration clause forms part of the main transactional contract, whether the claim is statute barred, failure to satisfy a condition precedent before submitting to arbitration, whether the agreement is valid and enforceable in accordance with law, ${ }^{24}$ whether the parties had consented by way of executing and appending their signature to the agreement, ${ }^{25}$ whether the agreement covered a particular dispute being referred, ${ }^{26}$ and whether on the basis of public policy and legislation a dispute with respect to a particular subject matter can be referred to arbitration ${ }^{27}$. However, only disputes and differences affecting peoples civil rights and obligations which can be compromised by way of accord and satisfaction may be referred to arbitration. ${ }^{28}$

In the narrow sense, arbitrability involves determining which type of disputes may be determined and resolved by arbitration and which belong exclusively to the domain of the competent courts. It also refers to matters which are specified by national law and municipal legislation to be incapable of resolution by arbitration. This definition of arbitrability in the narrow sense seems preferred and more plausible as it will lead to certainty in arbitration practice. Arbitrability is

23 Equitable Res Inc v. United Steel Workers Int. Union, Local 8-512. $621 \mathrm{~F} 3^{\text {rd }}$ $538,5506^{\text {th }}$ Cir 2010.

24 AT\&T Techs Inc v. Comm Workers 475 US 643 1986. Cox 533 F. 3d 1114.

25 John Wiley \& Sons Inc v. Livingston 376 US 543, 547 (1964)

26 Sherer v. Green Tree Servicing LLC 548 F. 3d 379, 381 (5 Cir 2008).

27 B. J. Export \& Chemical Co. Ltd (2002) LPELR 12175 where the Court of Appeal decided that the dispute which are the subject of an arbitration agreement must be arbitrable. In other words the agreement must not cover matters which by law of the state are not to be settled privately or by arbitration usually because this will be contrary to public policy. Thus a criminal matter, like the allegation of fraud raised by the respondent in this case, does not admit of settlement by arbitration as was clearly stated by the Supreme Court in K. S. U. D. B. v. Fanz Construction Co Ltd. (1990) 4NWLR (pt. 142) 1.

28 United World Ltd Inc v. M. T. S Ltd (1998 (10NWLR (Pt. 568) 106 however, a limitation placed upon arbitration by public policy consideration. Each State or country in accordance with its economic and socio political factors and consideration may decide which matters that will not be referred to arbitration. Therefore, there is no predetermined list or common factors for abitrability, but function of divergent considerations of tradition which vary according to jurisdiction.

\section{Arbitrability and Party Agreement}

As stated hereinbefore, arbitration agreement is the bed rock, foundation and the legal basis of every arbitral proceedings. The implication of this statement is that where parties failed to enter into an arbitration agreement before the commencement of the arbitration, then the subject matter is not arbitrable and arbitration proceedings cannot go further. Any arbitral award rendered without the arbitration agreement of the parties or outside the scope of the arbitration agreement is both void and unenforceable in law. In Chidi Ekwueme v. Sani Zakari, ${ }^{29}$ the parties who were in business had a dispute. The five mutual friends of the parties entered into the matter with intent to settle the dispute for them. At the end they reached a settlement. The applicant then applied to the High Court of the then East Central State of Nigeria for the enforcement of the decision (award) of their friends. The court (Hon. Justice Emmanuel Araka J.) decided that what went on between the parties and their five mutual friends was not arbitration hence the decision cannot be enforced as an arbitral award as there was no arbitration agreement between them to arbitrate. The parties have the right to specify the time within which arbitration may commence in their matter or dispute. Where the parties have specified time for arbitration, the arbitral tribunal has a duty to commence proceedings and make an arbitral award within the stipulated time. ${ }^{30}$ Where arbitration is commenced after the time specified then the matter is not arbitrable as the arbitral tribunal lacks capacity to arbitrate for them. It is important to state that there are situations where the parties may enter into an arbitration agreement with respect to a specific subject matter. The arbitral tribunal has jurisdiction and capacity to arbitrate with respect to that particular subject matter to the exclusion of any other subject matter. Arbitrability will also occur where parties agreed to arbitrate but the matter became statute barred as arbitration failed to take place within the time specified by the parties or the law of the state. ${ }^{31}$ The reason for this is that even if the arbitral tribunal goes on with the matter, at the end, the award rendered will be unenforceable in law.

\section{Arbitrability Based on Law and Public Policy}

According to the Blacks Law Dictionary, public policy means community common conscience, extended and applied

29 (1972) ECSLR

30 Arbitration and Conciliation Act Cap A18 L. F. N. 2004 section 17.

31 City Engineering v. Federal Housing Authority (1997) 9NWLR (Pt. 520) 244. 
throughout the state to matters of public morals, safety, welfare and the like, it is that general and well settled public policy opinion relating to man's plain, palpable duty to his fellow, having due regard to all circumstances of each particular relation and situation. ${ }^{32}$

We have both domestic and international public policy. In the domestic sense, public policy may be seen or regarded as the local standards or rules that are not subject to alteration or derogation by the parties and stand as an outside limit of the parties' freedom to contract. ${ }^{33}$ Public policy is general in terms but its actual content varies from country to country. For example, an arbitral award rendered pursuant to an agreement or contract on alcoholism may not be arbitrable and enforceable in a very strict Islamic state but will be enforceable in most other countries of the world. ${ }^{34}$ International public policies are those rules of a state's domestic public policy that will also be applied by the state in the international context. In the Arbitration and Conciliation Act of Nigeria, the term public policy (domestic and international) are not defined. This is dangerous because international arbitral awards may suffer impeachment purely on the basis of domestic public policy consideration.

National or municipal legislation including rules of courts of some States specified matters which may not be referred to arbitration. The content of the law and its provisions varied from country to country. In some countries, disputes arising under agreement of gaming or wagering and matters with respect to change of status such as divorce petition, cannot be referred to arbitration. Also a charge of fraud is not arbitrable. The limitation placed on arbitration from determining certain matters rests on two concepts imposed by statutes and the courts. The first being that certain disputes by their very nature and character fall within the exclusive jurisdiction of the courts based on certain constitutional provisions which cannot be negated by the provisions of arbitration law and agreement of the parties.

The second consideration is that there is a legal requirement that certain disputes by their peculiar nature should be determined in accordance with certain mandatory obligations of the municipal law. The first and second reasons for the restriction and limitation placed against arbitration are the same. The basic reason for requiring that court determines certain matters which is the fact of perception that only the court could correctly interpret the provisions of public law and give effect to the same in accordance with the wishes of the national parliament. Certain disputes are matters of public nature and concern hence the culprit must be punished for public good by the court of competent jurisdiction and not arbitral tribunal. According to Professor Parker in his article, "National Law and Commercial Justice"

The central theme in non-arbitrability cases is a concern

$326^{\text {th }}$ Ed. Centennial Edition, $1891-1991,1231$.

33 Greg. C. Nwakoby, The Law and Practice of Commercial Arbitration in Nigeria, $2^{\text {nd }}$ Ed, Snaap Press Ltd, Enugu Nigeria 2014, 324.

34 Buchanan, "Public Policy and International Commercial Arbitration" American Business Law Journal, No. 26, 1988, 511. that society will be injured by arbitration of public claims. Courts express fear that public law issues are too complicated for arbitration, the arbitration proceedings are too informal, or that arbitrators are like foxes guarding the chicken coop, with a pro-business bias that will lead to under enforcement of laws designed to protect the public...."

The public policy reason for non-arbitrability of certain matters and disputes are borne out of public desire to protect the state and public interest. ADR mechanisms generally are insulated from criminal offences due to public policy. ${ }^{35}$ The jurisprudential reasoning lies in the fact that the State exists to protect life and property. Any act or omission attacking the life of a member of the state or affecting the property interest of a citizen which is criminal in nature is an act against the State and has to be punished by the State. However, because of the prison congestion and slow pace of judicial proceedings within our jurisdiction, emphasis is currently being shifted and placed on the possible involvement of ADR (arbitration) in criminal matters. Dissolution of marriage celebrated under the Act (divorce) is also reserved for the High Court in Nigeria. Surprisingly, a condition precedent to filing of divorce matter in Nigeria is the requirement of attachment of the certificate of conciliation. The certificate is the evidence that parties were advised on the possibility of conciliation or that conciliation was tried but failed. This on its own shows that ADR could be used in divorce matters for if the parties had resolved their matter at the conciliation level, there would have certainly been nothing for the court to decide.

Issues of taxation and tax matters are not arbitrable in Nigeria for constitutional reason as the jurisdiction is vested on the Federal High Court. In SNEPCO \& 3 ors v. FIRS \& Anor, ${ }^{36}$ the Court of Appeal affirmed the earlier decision of Adam Bello J (Rtd.) of the Federal High Court Abuja Division that the outcome of arbitration proceedings between the NNPC and some IOCs on tax liability made pursuant to contractual obligation in a Production Sharing Contract (PSC) was not arbitrable because of the provision of section 251 of the Constitution. The court decided thus;

It is not therefore intended by the Constitution of the Federal Republic of Nigeria that issues of taxation or tax matters should go to arbitration. I hold that the claim of the claimant (defendant herein) submitted to arbitration having

35 S. C. Bennett, Arbitration Essential Concept, New York ALM Publishing 2002, 63-64 "Criminal cases which involve a public prosecutor representing public interest, are almost certainly not capable of arbitration. More difficult intermediate cases imbued with at least partial public interest include matters of child custody and bankruptcy." Moses M. L., Principles and Practice of International Commercial Arbitration, New York Cambridge University Press, 2008, 31 "In most jurisdictions, issues of criminal cases, family matters, child custody, and bankruptcy are inarbitrable. Most disputes are considered arbitrable except for those that fall within the clearly defined areas such as criminal law, family law, and patent law." Wilko v. Swan (1953) 346 US 427, 74 S. ct 182, 98 Led 168. The Supreme Court of the United States held that parties lack the capacity to consent to arbitrate security law claims as that will impair the effectiveness of such laws.

36 SNEPCO \& 3ors v. FIRS \& Anor CA/A/208/2012 delivered on $31^{\text {st }}$ August 2016 page 118 . 
been found to be related to tax disputes arising out of the operation of the PSC between the first defendant and the second to fifth defendants is not one referable to arbitration. The subject matter is one within the exclusive jurisdiction of this court granted by the Constitution.

In MV MSC Agata \& Anor v. Comet Shipping Agencies Nigeria $L t d^{37}$, the Court of Appeal decided that actions in rem are not ordinarily arbitrable given the subject matter which bothers on real property. The court defined action in rem as an action determining the title to property and the rights of the parties, not merely among themselves, but also against all persons at any time claiming an interest in that property. It is an action brought for the right of possession, ownership or other real rights in immoveable property.

The general attitude and practice of restricting and limiting ADR (arbitration) in criminal matters are fast giving way. This is because the pressures which favour ADR involvement in criminal matters outweigh the public policy reason against it. The court system is becoming greatly slow by the day. In criminal matters, not only the interest of the state is involved but the interest of the individuals wronged personally by the criminal act that need to be taken care of one way or the other. Criminal offence represents not just a violation of State but also a community conflict which requires resolution. The traditional criminal justice system is certainly incapable of taking care of all the interests involved in any particular criminal matter. Arbitration and other forms of ADR should be allowed in criminal matters to take care of the interest of the personal complainant that was injured or affected by the criminal event.

In Nigeria, plea bargain has been accepted as a means of determination of criminal matters in our courts. A lot of high profile cases have been determined through plea bargain which results by means of negotiated agreement between a prosecutor and a criminal defendant whereby the defendant pleads guilty to a lesser offence or to one multiple charges on exchange of some concession by the prosecutor usually a more lenient sentence or a dismissal of the other charges. ${ }^{38}$ Plea bargain allows both parties to avoid a lengthy criminal trial and may allow suspect and accused person to avoid the risk of conviction at trial on a more serious charge. The Administration of the Criminal Justice Act 2015 which came into force on $3^{\text {rd }}$ May 2015 came with it certain provisions on plea bargain. ${ }^{39}$ Plea bargain results from negotiation which is the first step in ADR hence the denial by the State of Nigeria that criminal matters are not arbitrable cannot be factual and correct. ${ }^{40}$ In the Nigerian Police station across the Federation

37 (2014) 1NWLR (Pt. 1388) 270.

38 Bryan Garner's Black Law Dictionary $8^{\text {th }}$ Ed. 1190.

39 Section 270 for plea bargain. Administration of Criminal Justice Law of Lagos State, 2007. Economic and Financial Crimes Commission (Establishment, etc) Act Cap E1 Laws of the Federation of Nigeria 2004,

40 FRN v. Igbinedion \& ors (supra). Gava Corp. Ltd v. FRN (2014) LPELR 22749. PML Nigeria Limited v. FRN (2014) LPELR 22767. FRN v. Cecilia Ibru (unreported). The only public outcry against these cases is that they were compromised because of the characters and the personality of persons involved in them. In Nigeria, a criminal matter involving stealing of one egg may lead to three years prison term as stealing is a felony whereas acts of corruption involving of Nigeria, criminal matters are often settled at the point of investigation by the parties with the assistance of the police officers. In the Magistrate and High Courts in Nigeria, criminal matters are often settled by the parties with the assistance of their counsel, friends or their family members. The only requirement being that where parties settle criminal matters outside the court during the pendency of the case in the court, the complainant must enter the witness box and give evidence on oath of the settlement and urge the court to strike out the case. However, arbitration should be encouraged in criminal matters with some level of limitations as to the categories of criminal matters that could be referred to arbitration. Allowing arbitration (ADR) into all aspect of criminal matters will destroy the very existence of man and the State. Arbitration should also be encouraged in divorce proceedings particularly in determination of formula for sharing of family property and custody of children. However, the involvement of arbitration in criminal matters in Nigeria is no longer in doubt as plea bargain constitutes one form of the same whereas the demand of certificate of conciliation as condition precedent in divorce petition pursuant to Matrimonial Causes Act is another instance of involvement of ADR in divorce matters.

\section{Law Governing Arbitrability}

In domestic arbitration practice, determining the applicable law governing arbitrability poses no problem because the State legislation, Constitution, the High Court Law, and particularly the governing law as agreed by the parties including the principles of domestic public policy of the State play vital roles in the matter. However, in international arbitration practice, the position is radically different and not an easy one.

In international arbitration practice, the question as to which law governs arbitrability has led to three different answers. The first approach being that the arbitrator shall determine the issue of arbitrability using and relying on the law which governs the arbitration agreement. ${ }^{41}$ This has the support of Article II (1) of the New York Convention which provides thus;

Each State shall recognize an agreement in writing under which the parties undertake to submit to arbitration all or any differences which have arisen or which may arise between them in respect of a defined legal relationship, whether contractual or not, concerning a subject matter capable of settlement by arbitration. ${ }^{42}$

In some cases, it may not be easy for the arbitral tribunal to identify the governing or applicable law to the arbitration agreement due to absence or failure of the parties to specify the governing law in their agreement. In such a circumstance, the arbitral tribunal shall assume the task of identifying and

ten billion naira results in three months jail term on plea bargain. The plea bargain system in Nigeria has to be streamlined.

41 Bernard Hanotiau, "What Law Governs the Issue of Arbitration? Arbitration International (LCIA) Vol. 12 No. 4, 1996, 391 at 393.

42 New York Convention $10^{\text {th }}$ June 1958, Article II (1). 
determining the applicable law. In Nigeria, the arbitral tribunal shall apply the rule as in section 47 (3) of the Act which provides that, "where the law of the country to be applied is not determined by the parties, the arbitral tribunal shall apply the law determined by the conflict of laws rules which it considers applicable." Once the arbitral tribunal has identified the substantive law which is applicable to the arbitration agreement, the arbitrator (s) shall relying on the same to determine the issue of arbitrability in the matter.

The second answer and approach to the question, is to apply the law of the place of arbitration as this is the law which will apply when application is filed in the court of place of arbitration for impeachment or setting aside of the arbitral award for reason of arbitrability. This second approach finds support in Article V (1) (a) of the New York Convention which provides that;

Recognition and enforcement of the award may be refused, at the request of the party against whom it is invoked, only if that party furnishes to the competent authority where the recognition and enforcement is sought proof that ...or the said agreement is not valid under the law to which the parties have subjected it or failing an indication thereon, under the law of the country where the award was made ${ }^{43}$

The choice of the law of the place of arbitration as the applicable law in determining arbitrability is both unacceptable and dissatisfactory for various reasons. The choice of venue as seat of arbitration is usually based on some socio economic and political factors. A venue is chosen because of its neutrality and convenience. At the time of choosing the venue, the legal system and rules of law of the venue may not be considered by the parties. A venue is also chosen because of its hospitable nature and also because of easy accessibility to the parties and their witnesses. It may also be chosen because of security reasons and availability of certain basic amenities.

The third approach is to determine the question in accordance with the law of the place of enforcement. ${ }^{44}$ This has the support of Article V (2) of the New York Convention which provides that;

Recognition and enforcement of an arbitral award may be refused if the competent authority in the country where recognition and enforcement is sought find that (a) the subject matter of the difference is not capable of settlement by arbitration under the law of that country; or (b) the recognition or enforcement of the award would be contrary to the public policy of that country.

The Arbitration and Conciliation Act of Nigeria has a similar provision as above. The Act provides that an arbitral

43 New York Convention Article v (1) (a). See also Arbitration and Conciliation Act Cap A18 Laws the Federation of Nigeria, 2004, section 52 (ii) which has a similar provision on the matter. It provides that the court before which an application for recognition or enforcement of an arbitral award is sought may refuse if the party against whom it is sought to be invoked furnishes the Court proof" that the arbitration agreement is not valid under the law which the parties have indicated should be applied, or failing such indication, that the arbitration agreement is not valid under the law the country where the award was made."

44 Antoine Kirry, "Arbitration: Current Trend in Europe" Arbitration International (LCIA), Vol. 12, No. 4, 273 at 380. award will not be recognized or enforced if the subject matter is not arbitrable or that arbitrating on it will be contrary to the public policy of Nigeria. It provides that the recognition and enforcement will be refused if the court finds-

(i) that the subject matter of the dispute is not capable of settlement by arbitration under the laws of Nigeria; or

(ii) that the recognition or enforcement of the award is against public policy of Nigeria. ${ }^{45}$

This reason that arbitrability should be determined based on the law of place of enforcement is a most unsatisfactory and unacceptable answer or approach in this matter as it is not always easy to determine where an arbitral award which has not been made would be enforced. An arbitral award may be enforceable in so many countries in which the defendant has assets to meet the demands of the arbitral award. This approach may lead to guessing where an arbitral award which has not been made could be recognized or enforced. The most acceptable and plausible approach is to determine arbitrability issue on the basis of the provisions of the law applicable to the agreement of the parties which had been specified by the parties or as determined by the arbitral tribunal in accordance with the provisions of section 47 (3) of the arbitration and Conciliation Act of Nigeria.

\section{Who Determines Arbitrability}

The question as to who has the jurisdiction to determine and decide the on issue of arbitrability has always been a controversial one as conflicting decisions exist on the matter. Whereas some courts have decided that it is for the courts to decide arbitrability of a matter, some scholars, text writers, and courts insist that it is for the arbitral tribunal to decide arbitrability as it is a jurisdictional matter challenging the jurisdiction of the arbitral tribunal to determine a dispute referred to it. A party challenging arbitration on the basis of arbitrability may question, for instance, the formal validity of the arbitration agreement or the existence of consent, or that the deadlines to commence arbitration have expired, or that the issue in contest is outside the scope of the arbitration agreement, or that the matter is contrary to public policy or that the subject matter is not arbitrable. In all, these issues are jurisdictional matters challenging the competence of the arbitral tribunal. Article 21 (1) of the UNCITRAL Model Law provides that "an arbitral tribunal shall have the power to rule and decide on objections that it has no jurisdiction including any objections with respect to the existence or validity of the arbitration clause...."A similar provision exists in the Arbitration and Conciliation Act of Nigeria which provides in section 12 (1) that "An arbitral tribunal shall be competent to rule on questions pertaining to its own jurisdiction and on any objections with respect to the existence or validity of an arbitration agreement."

In First Option of Chicago Inc. v. Kaplan ${ }^{46}$, First Options

45 Arbitration and Conciliation Act Cap A18 L. F. N. 2004 section 52 (2) (b) (iii). 46 First Options of Chicago Inc. v. Kaplan (1995) 514 US 938. 
entered into a debt recovery work plan with Manuel Kaplan, his wife carol Kaplan and Manuel Kaplan Investments Inc (MKI). This workout plan was made up of four separate documents to compromise debts recovery plans. However, only one document contained an arbitration agreement which was signed by Manuel Kaplan Investments Inc only, none of the Kaplans signed. A dispute arose when First Options seized and liquidated MKI's assets and demanded that the Kaplans make up the deficiency. When they failed to do so, First Options instituted arbitral proceedings against the Kaplan. The Kaplans alleged that the arbitral tribunal did not have the jurisdiction to entertain the matter because they (Kaplans) were not parties to any arbitration agreement. Thus, they petitioned the arbitrators on the issue of lack of signature.

The arbitrators continued with the arbitration and an award was rendered. The arbitrators held that:-

(a) The issue of lack of signatory authority was arbitrable;

(b) The arbitrators were the proper persons to decide on the arbitrability of the lack of signature;

(c) The Kaplans could be forced to arbitrate despite their lack of signatory authority.

The tribunal award was in favour of First Options. The Kaplans appealed against the award at the Federal District Court while First Options asked the court to confirm the award. The district court confirmed the award. On appeal, the judgment of the Federal District Court was reversed by the Court of Appeal and the Supreme Court. According to the Supreme Court, unless parties have agreed clearly and unmistakably to arbitrability, the court shall not assume that they agreed to arbitrate arbitrability. Thus there must be clear evidence that the parties agreed to arbitrate on the question of arbitrability. The courts are not allowed to infer it on the parties.

In Prime Paint Corporation v. Food \& Conklin Manufacturing $\mathrm{Co}^{47}$, the court decided that the matters concerning the arbitral contract are to be decided by the arbitral tribunal and the jurisdictional challenge based on the validity of the contract containing the arbitral clause, will be a matter for the arbitrator and not the court to decide. The principle as enunciated by the United States Supreme Court in Prime Paint and First Options respectively is that unless there is a clear and unmistakable evidence of the parties to arbitrate on the question of arbitrability, the courts should not input such an intention on the parties.

The position of the court in Prime Paint case was affirmed in Buckeye Check Cashing Inc. v. Cardegna, ${ }^{48}$ wherein the United States Supreme Court reversed the decision of the Florida Supreme Court that an arbitration agreement was void by its situation within an illegal contract. The Supreme Court held that,

(a) As a matter of Federal arbitration law, an arbitration provision is severable from the remainder of the contract.

47 (1967) 338 US 395.

48 (2006) 546US 440 (b) Unless the arbitration clause is being challenged, the validity of the contract is considered by the arbitrator in the first instance.

(c) This arbitration law applies in State as well as Federal courts. $^{49}$

In $A T \& A$ Technologies Inc v. Communication Workers of America $^{50}$ the United States Supreme Court decided that a party cannot be required to submit to arbitration any dispute which he has not previously agreed to refer to arbitration. This implies that once the issue in contention is whether the parties agreed to arbitrate or not, it is to the court that the matter should be referred. According to the court,

The question of arbitrability whether the agreement creates a duty for the parties to arbitrate a particular grievance is undeniably an issue for the judicial determination and unless the parties clearly and unmistakably provides otherwise, the question and whether the parties agreed to arbitrate is to be decided by the court and not the arbitrator.

The court in John Wiley \& Sons Inc v. Livingstone ${ }^{51}$ affirmed the decision in AT\&T Technologies by deciding that "the three fold questions as to whether the court or the arbitrator should decide whether the parties were bound to arbitrate was undoubtedly a matter for the court." The earlier text writers expressed the view that it is for the court to decide arbitrability and the issue as to whether the parties agreed to arbitrate or not. It is only after the court confirms that the parties did indeed agree to waive their right to dispute resolution in a courtroom can one be comfortable stripping the parties of their baseline juridical right and shipping them off to arbitration. ${ }^{52}$ On the other hand, the whole point of arbitration is to facilitate streamlined dispute resolution and get away from judges, marching off to court to clear the under bush of a threshold dispute may kill the very purpose for which the parties sought arbitration in the first place (even though one party resists its reach) non-judicial and speedy resolution of legal disagreement. ${ }^{53}$

In Nigeria, it will be wrong for any court to decide that the arbitral tribunal lacks the capacity and jurisdiction to decide the issue of arbitrability which is a jurisdictional matter. This is because the provision of section 12 (1) of the Arbitration and Conciliation Act provides that "an arbitral tribunal shall be competent to rule on questions pertaining to its own jurisdiction and on any objection with respect to the existence or validity of an arbitration agreement." It should be noted also that the issue of whether the court or arbitral tribunal should decide the matter of arbitrability depends on the stage at which the issue is raised. This is because the issue of arbitrability may be raised before the composition of

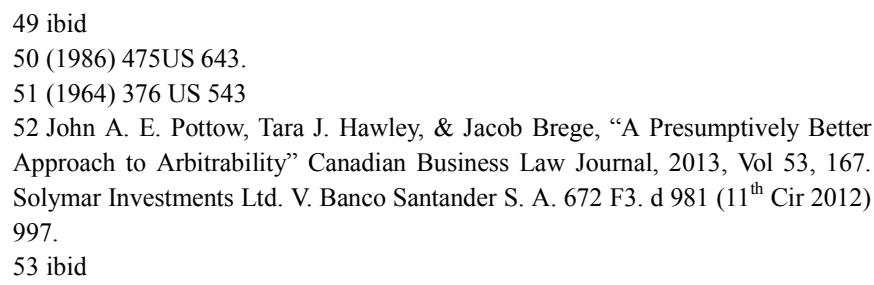


arbitral tribunal and commencement of arbitral proceedings, during arbitral proceedings or after the making of the award (at the stage of enforcement or impeachment). Where on the occurrence of a dispute and before the composition of the arbitral tribunal, a party to the arbitration agreement commences an action in court without first reverting to arbitration on the belief that the arbitral tribunal lacks jurisdiction to hear the matter, the court will have the right to decide the matter before granting and orderstay of proceedings in the matter. Where the matter is raised at the arbitral tribunal during the proceedings before the making of the arbitral award, the arbitral tribunal shall decide the matter in accordance with the provisions of section 12 (1) of the Act which deals with the principle of competence and competence. The principle of competence - competence simply means that the arbitral tribunal has the power to rule on any question relating to its jurisdiction or in other words, to the effectiveness of the arbitration agreement. However, where the issue is raised after the making of the award during enforcement or impeachment proceedings before the court, it is the court that should decide the matter. This is because the arbitral tribunal becomes functus officio immediately after making an award. The arbitral tribunal lacks the competence to deal with the issue of arbitrability after the arbitral award has been made.

\section{Conclusion}

Arbitration agreement is the bed rock and the legal basis of every arbitration proceedings. Arbitration agreement under the Act has to be in writing for it to be valid and enforceable. Arbitration has certain limitations placed against it by State legislation and public policy. This is because not all subject matters are possible of arbitration. Only matters which can be settled by accord and satisfaction can be subject of arbitration. However, there is no general list of issues which are not arbitrable as this varies from country to country. The fact of arbitrability is general but the content of it is relative. In some jurisdictions, matters of crime, divorce, antitrust, taxation, and fraud are not arbitrable. From the discussions so far, evidence abound that non arbitrability of criminal matter and divorce petition in Nigeria is not wholly factual as plea bargain proceeds from negotiation which is a form of ADR and settlement of cases takes place within the Police Stations in Nigeria. In both the High Court and Magistrate Court in Nigeria parties are often encouraged to settle their matters (criminal and civil) outside the court using ADR mechanisms. In divorce petition, one of the conditions precedent in filing the petition is a requirement of attachment of certificate of conciliation which has to evidence the fact that the parties (husband and wife) were advised to settle through conciliation or that conciliation has failed.

The law applicable in deciding arbitrability is the governing law which is applicable to the agreement which is specified by the parties in their agreement or the law as determined by the arbitral tribunal in the absence of parties' specification of the same. Though suggestions were made that the law of the place arbitration and the place of enforcement or impeachment should apply but these are not satisfactory. The determination of arbitrability could be taken by the court or the arbitral tribunal depending on the stage at which the issue is raised. Where the issue is raised during the arbitral proceedings before the making of an arbitral award, the arbitral tribunal shall determine the matter in accordance with the provisions of section 12 (1) of the Arbitration and Conciliation Act of Nigeria and the principles of competence - competence. However, where the matter is raised at the stage of enforcement or impeachment of an arbitral award before the court, the court shall have the jurisdiction to determine same. The reason for this is that the arbitral tribunal becomes functus officio immediately after making of an award. Arbitrability is general in terms but relative in content as it exists in all jurisdictions but its content varies from country to country.

\section{References}

[1] David St John Sutton, Russell on Arbitration, $22^{\text {nd }}$ Ed. Sweet \& Maxwell Ltd 2003, 26. Russell distinguished between arbitration agreement and submission agreement.

[2] Ibid $18^{\text {th }}$ Ed. 38. Russell in its $18^{\text {th }}$ edition confused two different forms of arbitration agreement.

[3] John Paris, The Law and Practice of Arbitration, George Godwin Ltd, Great Britain, 1974, 1.

[4] Ronald Berstein, Handbook of Arbitration Practice, 8.

[5] (2003) 15 NWLR (Pt. 844) 469 at 487.

[6] (2013) LPELR 20720. Agala v. Okusim (2010) 10NWLR (pt. 1220) 412 at 488. Ihunwo v. Ihunwo (2014) AllFWLR 1444 at 1453.

[7] Halsbury's Laws of England, $3^{\text {rd }}$ Ed, 38.

[8] (2006) NSCQR 77 at 112.

[9] (1856) 5 HL Cas. 811.

[10] Union of India v. Bhoriat Engineering Corp. LLR Delhi Series (1971) Vol. 2, 57.

[11] Arbitration and Conciliation Act Cap A18 Laws of the Federation of Nigeria 2004, section 1 (a) (b) (c) \& (2).

[12] Re Thompson (1894) QB 462. Tinplate Co. v. Hughes (1891) 60 LJ 189.

[13] David St. John Sutton, Russell on Arbitration $22^{\text {nd }}$ Ed. 435.

[14] Section 3 of the Act.

[15] Section 2 of the Act.

[16] Royal Exchange Assurance v. Bentworth Finance Nig. Ltd. (1976) 6 UILR (Pt. 2) 293.

[17] Afcon Nig. Ltd. V. Registered Trustees of Ikoyi Club (1996) FHCLR 371.

[18] Obemba v. Wemabod Estate (1977) 5SC 115. 
[19] Arbitration and Conciliation Act section 4 (1).

[20] Arbitration and Conciliation Act section 5 (1).

[21] KSUDB V. Fanz Construction Co. ltd (1990) 4 NWLR (Pt. 142) 1). Hallam v. Attorney General Plateau State (supra). 249. Commerce Assurance v. Alli (1992) 3NWLR (Pt. 232) 701.. Bebeji Oil Allied Products Ltd \& Anor v. Pancosta Ltd. (2007) 31 WRN 163. BSG Energy Holding Ltd v. Spears (2013) 31 WRN 146

[22] Equitable Res Inc v. United Steel Workers Int. Union, Local 8512. $621 \mathrm{~F} 3^{\text {rd }} 538,5506^{\text {th }}$ Cir 2010.

[23] AT\&T Techs Inc v. Comm Workers 475 US 643 1986. Cox 533 F. 3d 1114.

[24] John Wiley \& Sons Inc v. Livingston 376 US 543, 547 (1964).

[25] Sherer v. Green Tree Servicing LLC 548 F. 3d 379, 381 (5 Cir 2008).

[26] B. J. Export \& Chemical Co. Ltd (2002) LPELR 12175 where the Court of Appeal decided that the dispute which are the subject of an arbitration agreement must be arbitrable.

[27] United World Ltd Inc v. M. T. S Ltd (1998 (10NWLR (Pt. 568) 106.
[28] (1972) ECSLR.

[29] Arbitration and Conciliation Act Cap A18 L. F. N. 2004 section 17.

[30] City Engineering v. Federal Housing Authority (1997) 9NWLR (Pt. 520) 244.

[31] $6^{\text {th }}$ Ed. Centennial Edition, $1891-1991,1231$.

[32] Greg. C. Nwakoby, The Law and Practice of Commercial Arbitration in Nigeria, $2^{\text {nd }}$ Ed, Snaap Press Ltd, Enugu Nigeria 2014, 324.

[33] Buchanan, "Public Policy and International Commercial Arbitration" American Business Law Journal, No. 26, 1988, 511.

[34] S. C. Bennett, Arbitration Essential Concept, New York ALM Publishing 2002, 63-64 "Criminal cases which involve a public prosecutor representing public interest, are almost certainly not capable of arbitration. 